\title{
Fighting Work-Life Conflict: Strategies of Women Entrepreneurs of Fashion Industry of Pakistan
}

\author{
Aamna Mukhtar ${ }^{1}$, Rafia Faiz ${ }^{2}$
}

\begin{abstract}
In pursuit of improved flexibility and control over performance of dual roles in work and personal lives, an increasing number of women are shifting from paid employment to entrepreneurship. Yet, women entrepreneurs continue to experience dynamics of work-life conflict, particularly when gender interplays with culture, religion and class in unconventional, patriarchal Muslim societies. The purpose of this paper is to address the strategies adopted by Pakistani women entrepreneurs to combat work-life conflict. Border theory and role theory form the theoretical framework for this qualitative study. This study draws upon interpretive phenomenological approach (IPA) to examine lived experiences of coping with work-life conflict. In-depth interviews with 35 women entrepreneurs of fashion industry were conducted in mixed Urdu and English languages, transcribed verbatim, and analyzed thematically. Our study finds that women entrepreneurs experience varying degrees of work-life imbalance, and adopt active strategies to resist it. Due to poor institutional support, they largely tend to sacrifice their self-comfort for the sake of their family and business obligations. Strategic planning, authority delegating and seeking support from social capital are their most effective growth oriented strategies. Moreover, some women also practice growth constraining strategies in their subjective structures, thus contributing to reproduction of inequalities. This study contributes to expansion of border theory by highlighting the dynamics of work-life management when family and work are overlapping spheres for entrepreneurs. It adds to the growing body of literature on resistance and agency of marginalized women in emerging economies.
\end{abstract}

Keywords: Women entrepreneurs, work-life management, coping strategies, developing economy, Pakistan

\section{Introduction}

Women constitute approximately 40 percent of the global workforce (ILO, 2017), yet active participation of women across all levels of management hierarchy continues

1PhD Scholar, Institute of Business Administration, Punjab University, Lahore

Email:aamna_mukhtar@hotmail.com

2 Assistant Professor, Institute of Business Administration, Punjab University, Lahore

\section{ARTICLE HISTORY}

09 Sep, 2019 Submission Received 28 Jan, 2020 First Review

01 Nov, 2020 Second Review

22 Nov, 2020 Accepted 
to be met by a mosaic of challenges, including those pertaining to gender roles, cultural norms, religious misinterpretations and socio-economic class (Molina, 2020; Davies, Yarrow \& Syed, 2020; Agarwal \& Lenka, 2015; McBride, Hebson \& Holgate, 2015). As research on gender issues, particularly work-life balance in business management, has witnessed sporadic growth in the past two decades. International researchers (Sirgy \& Lee, 2018; Ozbilgin, Beauregard, Tatli \& Bell, 2011) seem to be converging to general consensus that work-life imbalance is potentially one of the overarching impediments to optimal utilization of women labour force. Moreover, cross-cultural examinations of work-life interface fail due to distinct cultural and business contexts of emerging economies (Allen, French, Dumani \& Shockley, 2020; Laudano, Zollo, Ciappei \& Zampi, 2019), including Islamic Republic of Pakistan (Syed \& Ali, 2019). Women continue to shift from paid employment towards home-based businesses in the expectation of lower work-life imbalance owing to better control and flexibility in both work and family domains (Adisa, Gbadamosi, Mordi \& Mordi, 2019; Ward, 2007; Rehman \& Roomi, 2012), yet, empirical evidence surrounding effectiveness of entrepreneurial ventures to mitigate work-family conflict remains scarce.

Here, work-family conflict is defined as the pressure faced by individuals in simultaneous performance of work and family roles and responsibilities; while work-life balance is considered the ideal or desirable equilibrium between homemaker and breadwinner roles, and work-life enrichment refers to the benefits that flow from performance of roles in one domain to the other (Greenhaus \& Parasuraman, 1999). In developing countries such as India, researchers suggest that demands by a thriving business offset benefits acquired by flexible boundaries; resultantly, development in work-life conflict is non-existential (Khandelwal \& Sehgal, 2018). These unintended consequences faced by women entrepreneurs are generally attributed to rigid gender role ideologies, poor time management, lack of adequate social support, caretaker responsibilities, and deteriorating health (Mathew \& Panchanatham, 2011; Casper, Vaziri, Wayne \& DeHauw, 2018). In light of weak institutional mechanisms, such as reliable childcare centers, acquiring and sustaining work-life balance becomes the responsibility of women entrepreneurs (Edralin, 2012). Women entrepreneurs are contributing over 50 percent to Gross Domestic Product (GDP) in various developed and emerging economies (Ojo, 2006). If work-life conflict is effectively reduced, women entrepreneurial ventures can make noteworthy contribution to economy (Agarwal, 2017). In this context, the purpose of this paper is to understand how women entrepreneurs in Pakistan manage their work-life conflict.

This study aims at contributing to the existing literature on entrepreneurship in several ways. First, we analyse the strategies used by entrepreneurs in family-business interface. A closer examination of the strategies used by women entrepreneurs has 
the potential to reveal knowledge of the combination of family responsibilities and business management can be dealt with, and increase our understanding of the social processes that link gender and family to entrepreneurship (Thébaud, 2016). Second, this study takes a work-life management perspective to the role of women in entrepreneurial ventures. The issue of work-life balance has achieved some attention in the literature (Martinengo, Jacob \& Hill, 2010), but has mainly been applied in a waged employment setting. However, as Jennings and McDougald (2007) proposed that the ways in which women entrepreneurs are able to solve work-life balance issues may be related to business development and growth (Agarwal \& Lenka, 2015), as well as to choices of becoming and sustaining entrepreneurial identity (Thébaud, 2016). Third, existing literature has particularly emphasized on the antecedents and consequences of work-life conflict (Byron, 2005; Poggesi, Mari \& De Vita, 2019) whereas strategies adopted by women entrepreneurs to integrate their business demands with their family obligations are scant. Hence, this study also addresses this gap by identifying and categorizing such strategies, examining how women entrepreneurs manage their ventures whilst balancing demands beyond the challenges of the business.

\subsection{Empirical frame of reference: Context of Pakistan}

Economic, social, technological and political vicissitudes have helped in emerging new social structure that facilitates women to work and not to remain confined in their houses (Rehman \& Roomi, 2012). However, unlike other developed and developing countries, women in Pakistan face more difficulty in managing work and family in a patriarchal society where the major responsibility of a woman is family care (Faiz, 2015). The historical belief of women as "house makers" exerts more pressure on women entrepreneurs to manage work family roles. Child care responsibility primarily falls on women hence making motherhood impassable as compared to fatherhood (Gronlund, 2007). As a result nearly 65\% of female doctors and $80 \%$ of business graduates in Pakistan do not work after marriage (Hakeem \& Aijaz, 2017).

Systematic subordination does not allow women to express their full potential irrespective of the class and region they belong to. In Islamic societies (e.g. Pakistan), men are segregated in two groups i.e. "Mehram" and "Na-Mehram". Mehram refers to those men with whom marriage is explicitly forbidden (e.g. father, brother, nephew, uncle, Father-in-law). Na-Mehram are those with whom there is no impediment for marriage (Mazumdar, 2001). All men other than Mehrams are regarded as Na-Mehram. In Pakistani society, men have power over woman to shape and influence their decisions based on their gender (Faiz, 2015). Hence, important decisions of their life (education, career, marriage) are being made by their "Mehrams". Women tend to sacrifice their dreams due to their family norms and social boundaries. Structural 
barriers in Pakistan restrict unaccompanied mobility of women outside their homes (Ozbilgin, Syed \& Dereli, 2010). Interaction of women with "Na-Mehram" is considered as problematic which may point question mark on her family respect (Mazumdar, 2001). Unsurprisingly, employment rate of women in Pakistan is the lowest in the world (4.3\%). According to the Labour Force Statistics (2017), the economic participation of women in Pakistan remains very low although they hold $47.23 \%$ share of the total population. The rate of female participation in economic activity is $22.6 \%$ (LFS, 2017) because of the inherent gender biasness in the male dominated labor market of Pakistan and limited occupational choices due to social and cultural constraints (Ali, 2013). Khan, Naveed, and Hamzah-Bin-Jantan (2018) referred to UN women report 2016 that only $30 \%$ of women and 3\% of men are home-based workers who contribute 400 billion rupees that accounts for $3.8 \%$ of GDP.

\section{Literature Review and Theoretical Framework}

Work/family border theory of Clark (2000) provides the foundation for the concept of work life management. According to this theory, work and family domains are separated by physical, temporal, or psychological boundaries and for effective management of one's work and family roles one has to cope with these physical, temporal, or psychological borders. Flexibility and permeability of these boundaries facilitate integration between work and family roles (Bellavia \& Frone, 2005). We base this study on border theory to explore how subjective perceptions of balance and boundary management might illuminate coping strategies.

Work and family are two important domains of life but there are many other aspects of one's personal life that can intersect with work and family such as health, comfort and leisure. Hence, work-life refers to the intersection of work, family and self-needs. Work-life management is the ability of an individual to effectively meet his work and family commitments, as well as his own non-work responsibilities and activities. Need for maintaining work-life balance has been widely acknowledged by both employees and managers as it affects their performance (Bird, 2006). Literature reveals that sustainable balance of work, family and life spheres is a continuous struggle (Faiz, 2015). Hence, effective management of time, strain and behavior within the work and family domain is more important than seeking to maintain balance between the two domains. The "cross-domain effects" (Friedman \& Greenhaus, 2000) exist in the relationship of work and family domains. So, it is not about balancing or equalizing both roles but setting your priorities depending on the urgency, intensity and severity of a particular role. Management of work and family roles depends on the competing expectations and demands hence working women find it most challenging to juggle these expectations and demands (Rehman \& Roomi, 2012) due to less flexibility and 
permeability between work and family boundaries.

Consistent with the family embeddedness perspective (Aldrich \& Cliff, 2003), the literature on women's entrepreneurship has suggested that women's family obligations and other domestic responsibilities strongly influence their choices to become an entrepreneur, as well as strategic choices in their businesses (Brush, De Bruin \& Welter, 2009; Jennings \& Brush, 2013; Thébaud, 2016). Family and other domestic responsibilities are sometimes seen as an incentive for women to choose self-employment over paid employment, when the latter is associated with less flexibility and autonomy (Thébaud, 2016). In line with this argument, the concept of 'mumpreneurship' has been introduced to portray women's balancing of multiple roles as entrepreneurs and mothers (Duberley \& Carrigan, 2012; Ekinsmyth, 2014). Hence, for some women entrepreneurship is a way to combine career and family life; i.e. to earn an income and still manage child-care responsibilities. These arguments are rooted in the persistent sex-roles and gendered division of labour we find in all societies.

Flexibility is the main motivation for females to enter in self-employment (Rehman \& Roomi, 2012). De Lange, Kooij, and Heijden (2015) argued that men give more priority to work related tasks whereas; women generally prioritise family roles to their employment tasks. Flexible work schedules provide an opportunity to women to balance their work and family roles (Baughn, Chua \& Neupert, 2006; Agarwal, 2017; Gupta, Turban , Arzu \& Sikdar, 2009) and also help them in minimizing the strain of childcare (Joona, 2018). Various researchers have reported that marriage and childcare are among the most influential factors for women entrepreneurship (Rehman \& Roomi, 2012; Joona, 2018). Childcare responsibility predominantly falls on women that suggest women need multi skills to manage business and family. The entrepreneurial process provides more control and flexibility in a work schedule and working environment than a job (Rehman \& Roomi, 2012). For women entrepreneurs, home based business allows more ease to manage entrepreneurial activities and family obligations but it does not mean that she will not face any conflicts (Goffee \& Scase, 2015)

However, women's family responsibilities have also been suggested to inhibit entrepreneurship, such as constraining the time and efforts women entrepreneurs are willing or able to put into the business, restricting growth ambitions or reducing the willingness to take risks (Simon, Houghton \& Aquino, 2000). As entrepreneurs are part of a gendered society that constructs women and men as different, male and women entrepreneurs face different expectations of how they "should" behave (Xia, 2015). Society primarily assigns family care to women and paid labour to men and the expectations to male and women entrepreneurs accordingly (Rehman \& Roomi, 
2012). Hence, experiences that business activities may not always be profitable for families (Jennings, Breitkreuz \& James, 2013), may lead women concerning for their family to constrain their entrepreneurial efforts.

Family embeddedness of entrepreneurship (Aldrich \& Cliff, 2003) implies that entrepreneurs, their families and their business are interwoven (Jennings \& McDougald, 2007). The embeddedness is manifested different ways in the three spheres. From the business perspective, the family sphere is often presented as a liability for the entrepreneur, for example by inflicting work-family conflicts (Jennings \& Brush, 2013; Shelton, 2006) and stress (Greenhaus \& Parasuraman, 1999). Further, responsibilities in the family sphere are claimed to decrease the human capital available to the business (Rothausen, 2009), and, hence, to result in inferior business performance ( Jennings \& Mcdougald, 2007; Shelton, 2006). On the other hand, the family can also represent an asset for the entrepreneur (Eddleston \& Powell, 2012), giving access to support and crucial resources for the business (Alsos, Ljunggren \& Carter, 2016).

From the family perspective, the business sphere is usually portrayed as an asset, supporting the family financially and creating wealth. Further, the business can create job opportunities for the next generation, as well as job training and entrepreneurial experience during young age (Alsos et al., 2016). However, though less seldom advocated in the literature, business ownership is not always good for families (Jennings et al., 2013). The business may demand huge amounts of time and effort that is not always compensated for, it can lower marital stability, well-being and life satisfaction.

For the entrepreneur, achieving some sort of balance between the business and the family spheres is important (Jennings \& McDougald, 2007), as they usually consider both spheres as important to them. Further, a balance between work and family life gives psychological health and well-being (Greenhaus \& Allen, 2011). Until recently, the issue of work-life management has been scarcely examined and discussed in relation to entrepreneurship (Ezzedeen \& Zikic, 2017), which is surprising given the role family is assumed to play, particularly for women entrepreneurs.

Building upon the above literature, Figure 1 offers an overview of conceptual framework developed to guide empirical analysis. We suggest that work-life conflict management strategies of women entrepreneurs depend on a medley of business characteristics, family characteristics and personal characteristics. 


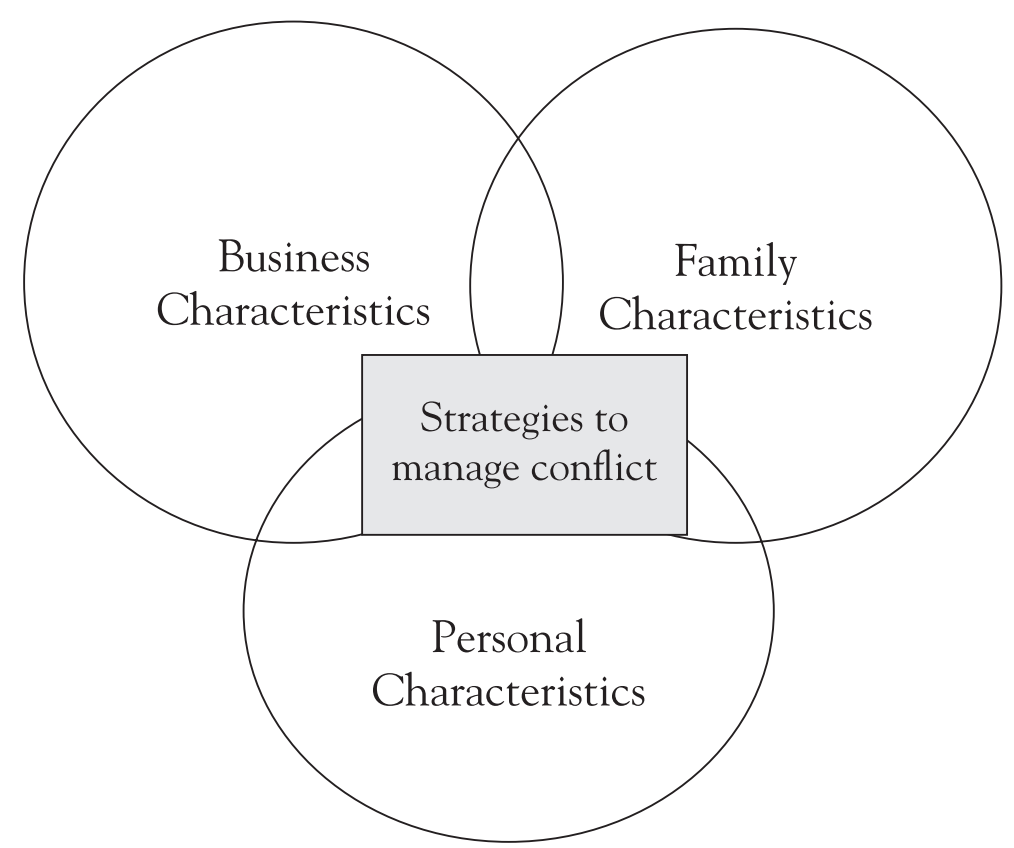

Figure 1: Multilevel Factors Influencing Work-Life Balance Strategies of Women Entrepreneurs

\section{Research Method}

This phenomenological study is aimed to seek new insights into work-life management strategies opted by women entrepreneurs. Thirty-five women entrepreneurs were interviewed in order to examine their lived experiences. The philosophy of critical realism (Creswell, 2014) is used to understand the influence of social structures on work life issues of women in Pakistan. We have adopted subjectivism and retroduction as our ontological and epistemological position in order to examine the multifaceted interplay of culture, gender and religion that influence the ways to cope with work-life conflict.

\subsection{Sample}

Thirty-five women entrepreneurs were selected by purposive and snow ball sampling from major cosmopolitan cities of Pakistan i.e. Lahore, Faisalabad, Islamabad, Multan and Karachi. Researchers contacted key informants from Small and Medium Enterprise development authority (SMEDA) and Women Chamber of Commerce for the selection of women entrepreneurs for this study. Based on the gender specific definition of entrepreneurship of Anwar and Rashid (2012), this study defined women entrepreneurs as "women who utilize their resources and knowledge for the 
development or creation of new business opportunities whether formal or non-formal, registered or non-registered, home based, office based or in virtual environment (online Business). Who are actively managing their business and are responsible for their business operations on daily basis (self-adjusted timings) and have setups for more than a year".

Sample of the study are the women entrepreneurs from fashion industry as Pakistan development update reported that $75 \%$ on women entrepreneurs in Pakistan are concentrated in service sector i.e. salons, apparel and education (World Bank, 2017). Fashion industry includes small/medium (SME) fashion retailers (Barsh, Crawford \& Grosso, 2000), fashion luxury brands (Ko \& Megehee, 2012), fashion e-retailing and Blog Shops (Yeung \& Ang, 2016). Fashion e-retailing includes well-established and registered online fashion retailers whereas blog shops are mainly non-registered and inexperienced entrepreneurs who sell their products through blogs (Yang, Song $\&$ Tong, 2017). Hence, this research has included the diverse range of entrepreneurs from fashion industry such as fashion luxury brand owners, dress designers, jewelry designers, fashion consultants, fashion e-retailers, fashion photographers and small/ medium-sized fashion retailers (e.g. boutique and salon owners). Fashion industry is considered as most suitable sector for women where women are seen at different levels, ranging from home based business to state level. So, to address the research objectives, this sector is most suitable as there are various women entrepreneurs who are actively contributing towards their family and state economy and making a good image of Pakistan all across the globe.

Participation invitations were distributed at entrepreneurial meet-ups, conferences and in their offices (through appointments). The details of the study were also posted on social media pages related to women entrepreneurs. It is important to note that researchers did not offer any incentive to participants. The participants had different levels of education i.e. 29 per cent of women with a lower level of education whereas 71 per cent were well educated which reflects a demographic change in the education level of women in Pakistan (Amjad, 2013). The women were between 18 and 57 years old with an average age of 35 years. The demographics of the participants are provided in Appendix A.

\subsection{Procedure}

Semi-structured, face-to-face interviews were conducted in English and Urdu languages as per the convenience of the participants. Participants were asked to withdraw their consent for participating in the study at any point of time if they feel like. They were not even required to explain the reason for their withdrawal. Interviews were audio-recorded with prior consent of the participants. The researchers also maintained 
a research diary in which she noted important aspects of the participants, ambiances and influencers. The interviews lasted between 50 to 90 minutes. Each interview was given a symbolic code to ensure the conditionality. First author conducted, translated, transcribed and analyzed each interview on her own as it helps in interpretations and sense-making process. The qualitative transcripts offer a number of functionalities such as recording of mechanisms and patterns of speech(naturalism), to captivating meanings and perceptions (denaturalism) (Oliver, Serovich \& Mason, 2005). The choice of the transcription method predominantly depends on the research aims and objectives (Patton, 2002). The research aim of this study is to work-life experiences of women entrepreneurs; hence more importance should be given to the contents of the interview rather than patterns of the speech. Since English is not the first language of the both researchers and the participants so grammatical errors were corrected in the transcription in denaturalized style. So, the final style of transcription was based on denaturalism.

\subsection{Analysis}

Data was analyzed by interpretative phenomenological analysis (IPA) approach (Smith, 2004). IPA approach provides a thorough analysis for the response of each participant's response in relation to their personal experiences. Researchers identified emerging codes and themes from the data after reading the transcripts carefully. Some themes were expected based on the literature such as flexibility in work schedules and redesigning of work settings. Other themes, such as foregoing business opportunities and sacrificing expansion were not expected but emerged naturally from the data. Researchers paid special attention to the wording of the interviewees while assigning new codes to the transcripts. Research diary was also consulted during the process of data analysis.

First column of Table 1 represents different concepts that emerged from wording of the interviewees; second column signifies the high-level abstracted themes derived from these concepts. Finally, aggregated theoretical dimensions and categories are created to build the relationship among themes.

\section{Findings and Discussion}

Work-life interactions always seem to be complicated as the expectations from both domains can be highly demanding. Table 2 presents an overview of the findings revealing a number of strategies and tactics that women entrepreneurs use to manage their business and family commitments. According to the analysis, the emerging themes were grouped into two broad categories i.e. Growth oriented strategies and Growth constraining Strategies. 
Table 1: The Data Structure

\begin{tabular}{|c|c|c|c|}
\hline Concept discussed & $\begin{array}{l}\text { Emerging } \\
\text { themes }\end{array}$ & $\begin{array}{l}\text { Theoretical } \\
\text { dimensions }\end{array}$ & Categories \\
\hline $\begin{array}{l}\text { Observations about responsibilities } \\
\text { towards work, society, family and time } \\
\text { Becoming aware of family needs and } \\
\text { career aspirations that tend to compro- } \\
\text { mise on self }\end{array}$ & $\begin{array}{l}\text { Time manage- } \\
\text { ment }\end{array}$ & Work to family & \multirow{3}{*}{$\begin{array}{c}\text { Growth oriented } \\
\text { strategies }\end{array}$} \\
\hline $\begin{array}{l}\text { Delegating responsibilities to staff in } \\
\text { order to manage conflict } \\
\text { Preparing team for uncertain circum- } \\
\text { stances } \\
\text { Hiring staff to manage workload }\end{array}$ & $\begin{array}{l}\text { Building } \\
\text { reliable team }\end{array}$ & Work to family & \\
\hline $\begin{array}{l}\text { Personal preference of staying at home for } \\
\text { childcare } \\
\text { When career aspirations are low as com- } \\
\text { pared to the motherhood } \\
\text { When work is important to run family } \\
\text { needs as well as care for baby and main- } \\
\text { taining career track is equal important }\end{array}$ & $\begin{array}{c}\text { Redesign } \\
\text { work settings }\end{array}$ & Work to family & \\
\hline $\begin{array}{l}\text { Perceptions about hired help } \\
\text { Help from family members/partner } \\
\text { reduce pressure on work } \\
\text { Sharing ideas about cultural aspects on } \\
\text { leaving the kids at daycare } \\
\text { Discussing child rape/security issues and } \\
\text { reliable family custodians }\end{array}$ & $\begin{array}{c}\text { Seeking } \\
\text { support from } \\
\text { social capital }\end{array}$ & Family to work & \multirow{3}{*}{$\begin{array}{l}\text { Growth constrain- } \\
\text { ing strategies }\end{array}$} \\
\hline $\begin{array}{l}\text { Perceptions of unmanageable conflict } \\
\text { Motherhood responsibilities and social } \\
\text { constraints } \\
\text { Disapproval from others/partner }\end{array}$ & $\begin{array}{l}\text { Foregoing } \\
\text { business op- } \\
\text { portunities }\end{array}$ & Work to family & \\
\hline $\begin{array}{l}\text { Personal preference that lead to sacrifice } \\
\text { career for sake of family } \\
\text { Mindset that primary responsibility is } \\
\text { childcare }\end{array}$ & $\begin{array}{l}\text { Sacrificing } \\
\text { expansion }\end{array}$ & Work to family & \\
\hline
\end{tabular}

Note: Table represents the data structure to epitomize the transparency of data analysis 
Table 2: Strategies to Cope with Work-Life Issues

\begin{tabular}{|c|c|c|}
\hline Strategy dimension & Growth Oriented Strategies & Growth Constraining Strategies \\
\hline \multirow{2}{*}{ Work To Family } & $\begin{array}{c}\text { Time management } \\
\text { Building reliable team } \\
\text { Redesign work settings }\end{array}$ & $\begin{array}{c}\text { Foregoing business opportunities } \\
\text { Sacrificing expansion }\end{array}$ \\
\hline Family To Work & Seeking support from social capital & \\
\hline
\end{tabular}

Note: Table shows the themes emerged from the strategic dimensions of the work-life interface.

\subsection{Time management}

Most of the participants suggested that effective time management is the key to maintain a healthy balance between family and business. Women in Pakistan have to fulfill their duties at work as well as at home. Women have to bear double pressure i.e. to be an ideal worker and ideal homemaker. The historical role of women was childcare and home making hence same is expected from working women of present era. Therefore, women entrepreneurs have to sacrifice their own ease and comfort to timely manage the responsibilities of both family and work domains. A participant narrated that "I usually do creative work at night or afternoon when my kids are sleeping" (P-7). Many women entrepreneurs talked about their daily routine that they do all household chores early morning (i.e. preparing food for family and housekeeping activities) before going to their business. McGowan, Redeker, Cooper, and Greenan (2012) also reported that time management plays a significant role in coordinating various identities and roles of women entrepreneurs' daily life such as daughter-in-law, mother, wife, a caregiver, and business holder. A participant shared her experience:

Charm of self-employment is that you can manage your time according to your ease. But yes it's tough, very, very tough, like when my children were young, I sent my children to school, did all household chores, attended to my husband, and even in Ramadan in summer, I had to visit markets to purchase material for my business, all this had to be done before my children returned (P-9)

The majority of married women with young children have to follow a tough routine while managing their time but the women with grown up children find their time management relatively easy. A participant with grownup children narrated that "My 
daughter is now college student and son is abroad for studies. They have their own routines so it's quite easy for me to manage my time for work" (P-5). When children are less dependent on their mother then it is increasingly possible, desirable and easy for women to manage their work and family.

\subsection{Building reliable team}

Findings suggest that responsibility sharing and authority delegation is the perfect way to lessen the work family conflict for women entrepreneurs. There is a concept of "solopreneur" for small business owner. However, even for small businesses women entrepreneurs of Pakistan tend to hire at least one employee to help them in their business and share their burden. As narrated by a participant "I give fulltime to my work. Nevertheless, if there is any issue which is unavoidable then I have employees. They manage in my absence" (P-3). Training your employees is a bit of pain but eventually it pays huge dividends as it allows you to be relieved from overburdened dual roles. One participant shared a horrendous experience of family tragedy leading to work-life conflict:

One of my grandsons was burnt in a domestic fire. He was in the hospital, I had to visit him, yet on the same day, I had booking for bridal makeup. I couldn't do both. So I asked my staff member to attend to the bride in my absence, and I barely managed to reach back to the salon in time for finishing touches to the bride's makeup. It was a nightmare. (P-6)

The importance of the women's agency is highlighted in the above accounts while dealing with complex structural challenges. Her expression showed her concern for her business due to her family-oriented approach. However, she tried to manage the situation with task delegation and a multitasking strategy to address this structural and situational challenge. Various scholars (Ekinsmyth, 2011; Shah, 2014) also report the use of such strategies by women entrepreneurs. Ruderman, Ohlott, Panzer, and King (2002) reported that women as managers develop several skills such as multitasking skills, interpersonal skills and task delegation to improve their administrative effectiveness.

\subsection{Redesign work settings}

In our study, women entrepreneurs reported home-based business as a success strategy to reduce work-to-family interference as it provides greater life satisfaction with better time management ability. Working from home enables the women to take care of their home and children (feeding them and helping them with homework) along with the business activities. A woman entrepreneur with a home-based business 
narrated: "Clients can drop in my home anytime between 8:00 am to 9:00 pm. I don't have many clients, so I catch up on my household in the free time. I would say it is fine, no serious conflicts" (P-34). Life experiences suggest that instead of flexible and permeable boundaries, home-based businesses facilitate women entrepreneurs to minimize their work-life issues. Because ease in transition and high level of integration between work and family domains allows nursing mothers to feed their infant as and when required. According to border theory, work and family domains are separated by psychological, physical and temporal borders (Clark, 2000). Working from home halts the physical boundary yet increases the level of integration between work and family domains. Bellavia and Frone (2005) reported that if boundaries between work and family domains are flexible and permeable then work-family conflict is likely to be high due to the ease in transition. Conversely, this study has found that instead of flexible and permeable boundaries, working from home lessens the work-family conflict for the women entrepreneurs with infants and young children. Because ease in transition and high level of integration between work and family domains allows nursing mothers to nourish their infant as and when required. An entrepreneur with an infant explained her business routine as

I think a major benefit of running an online business is that there are no time constraints. I start work whenever I wake up. My work routine revolves around my daughter's routine. I can pause my work at any moment to attend my daughter, which I wouldn't have possibly done if I were working in a corporation. Now, I can even step out for shopping in her nap time. (P-30)

Re-designed work settings such as online retailing and blog selling also facilitate women entrepreneurs for effective work-life management along with financial benefits.

\subsection{Seeking support from social capital}

Women entrepreneurs of Pakistan try to reduce their work family conflict by seeking support from social capital (husband, parents, in-laws, siblings, maids and nannies). In the socio economic culture of Pakistan, in some areas women are not allowed to go out or move freely, even driving a car and interaction of women with "Na-Mehram" or strangers can be seen as shaming the family's honour (Arifeen, 2008). Many participants spoke proudly of receiving support of the men in their family, from finding a suitable venue, to filing taxes, to liaising with market suppliers.

Mokomane (2014) reported that women rely on unpaid family support to manage some responsibilities such as caring for family. A participant narrated "I leave my kids to my mother-in-law. She feeds them and takes care of them when I am not at home" 
(P-12). The joint-family system can be seen as absorbing work life conflict of working women (Ozbilgin \& Syed, 2010) due to the division of household responsibilities among all the women in the house. Similarly, joint-families in Pakistan are based on trade-offs association that provides free and reliable childcare.

In the family sphere, outsourcing domestic labor is a common practice in Pakistan to reduce work-life issues. Women entrepreneurs usually hire maids through their own economic capital to help them with cooking, cleaning, and laundry. However, women entrepreneurs do not completely rely on maid for child care. As a participant shared "I take my younger daughter and maid to salon with me as there is no one at home. I can't leave my maid alone at home" (P-11). Leaving children 'alone' with the maid is not a preferred choice for some women entrepreneurs owing to weak law and order mechanisms in Pakistan. Moreover, domestic help is vulnerable, unrecognized form of employment, that is not protected by labour laws (Faiz, 2015). Child abuse by maids is unfortunately a prevalent problem in Pakistan. In line with this finding, Helmy, Aljiuad, Alsufyani, Alsufyani, and Alkhadi (2017) also reported that educated mothers seem to be aware of different types of child abuse. Hence, the reported success strategy is to take their infants and maids to their office, where the periodic presence of mother or other staff members does not grant absolute privacy to the maid, thereby, lowering the chances of child abuse and neglect. This strategy helps them in maintaining the image of an "ideal mother" who takes care of her children all the time while fulfilling the role of a successful entrepreneur.

\subsection{Foregoing business opportunities}

Findings suggest that women are more likely to engage in such strategies in which they compromise on their business growth and let the opportunities to forego at that time. Most of the entrepreneurs with children reported that they cannot exercise their full potential due to the family obligations. A participant shared "I usually don't go for foreign exhibitions just because of my children" (P-15). Another participant shared, "My husband does not like my interaction with media and men, you know what I mean. So I don't appear on TV. I don't post pictures on Instagram. I don't want to upset my husband" (P-7). The interaction of women with men can threaten her 'izzat' leaving a question mark on her family honor. In Pakistan, "Mehrams" draw the boundaries for women and they have to seek their permission for their every action. Various feminist researchers (Ali, 2013; Arifeen, 2008; Faiz, 2015; Rehman, 2015) affirm these notions by stating that conservative practices attempt to keep women out of the labour market in Pakistani society. Women entrepreneurs in the study have reported that keeping their "Mehram" happy is the success strategy to minimize work family conflict yet it limits their business growth but still keep their 
home environment contented. These accounts are supported by the arguments of Marlow and McAdam (2013) who explained that woman's choices are constrained, which does not mean they underperform, rather they are not given the environment to perform, and hence, their performance is constrained.

\subsection{Sacrificing expansion}

Although research indicates that women, in general, tend to emphasize both work and family roles simultaneously throughout the life course, but current study provides evidence that if the start-up or expansion of business challenge to ruin the family relationships then women entrepreneurs tend to compromise on their business rather than compromising on their family. One participant explained that

When I started my business, my daughter was of 12 years, you know that in teen age girls need utmost attention of their mothers. Otherwise they may indulge in bad company. In the beginning, my business also required my full attention. Consequently, I decided to forget about new branches and expansion for some time so that I can pay proper attention to my daughter. Businesses may start again at any time but family may not (P-5)

These findings signify various socio-cultural constraints that a woman faces while operating in a patriarchal society. Women entrepreneurs will be more likely to make the converse decision and postpone business start-up or expansion until their family responsibility level and/or household time demands are lower (Jennings \& Mcdougald, 2007). This universal problem is echoed by other scholars (Al-Dajani \& Marlow, 2010) of patriarchal societies who claim that women entrepreneurs in small businesses refuse work to deal with family obligations. They proudly put their families ahead of their business without having any concern for expansion. Findings of the study are summarized in an analytical model given below in Figure 2. 


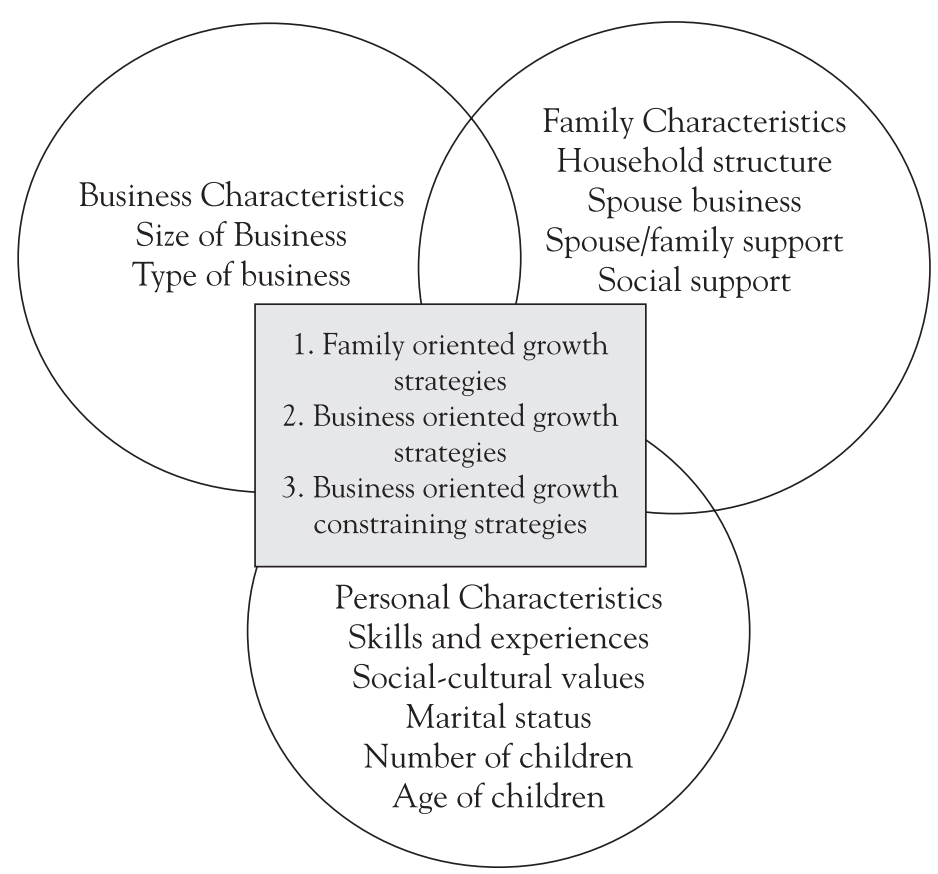

Figure 2: Work-Life Management Strategies of Women Entrepreneurs

The model shows that the women entrepreneurs practice growth oriented and growth constraining strategies in order to manage their work and family roles, depending on their business characteristics (size and type of business i.e. online, home-based or traditional office-based business), personal characteristics (skills, experiences, marital status, socio-cultural norms, number and age of children) and family characteristics (household structure, spouse business, spouse/family support, social support).

\section{Conclusion}

Findings suggest that women entrepreneurs of Pakistan seem to be admitting that their breadwinner role is not legitimate and it depends on their multi-tasking skills and management strategies to deal with organizational and societal demands. Work-life conflict and balance are not solely determined by one's occupation; rather, they also reflect the individual entrepreneur, specifically his or her perceptions and attitudes toward work-life balance and concurrent boundary management strategies. Contrary to the idea of Ashforth, Kreiner, and Fugate (2000) that individuals choose integration or segmentation primarily to balance work and family. To meet the work demands, this study corresponds with the findings of Ezzedeen and Zikic (2017) that integration can be chosen to prioritize work; individuals can purposefully espouse conflict-causing integration strategies. Women entrepreneurs lay out their success 
strategies to minimize business and family conflict but they are also aware of uncertain support structures at work and family domains that may require improvised judgments. However, there are limited choices available for women entrepreneurs subject to their idiosyncratic structures. Women entrepreneurs cope with their work life conflict by scheduling their business and family roles according to their urgency, reducing their work load by delegating work to employees, and flexible work assignments for themselves and their workforce.

Findings suggest that the pressure of work-life conflict management is predominantly absorbed by oneself. Women entrepreneurs sacrifice their self-comfort and coziness in order to manage business and family roles i.e. scheduling the chores at the beginning of each day, listing the things to be done and prioritize them. Women entrepreneurs set up their routine according to the importance and urgency of their tasks, and sought what can be delegated or postponed. Women entrepreneurs seek support from their family and spouse. Developing and maintaining family support system is important for entrepreneurial career especially for married women due to the dynamic expectations of home and childcare. Family must understand the dual role demands and expectations from women entrepreneurs and try to encourage them in order to raise their confidence. The husbands should offer domestic help and assistance in childcare responsibilities to mitigate the burden from women entrepreneurs to acknowledge their participation in sharing the economic burden of family.

\subsection{Theoretical implications}

Our study contributes empirically to the knowledge base how entrepreneurial decisions, processes and outcomes influence and are influenced by the family sphere. We found that the strategies adopted by women entrepreneurs are in response to current ideas in society, discourses on what an entrepreneur is, what motherhood represents, and about being a woman in a patriarchal society. Hence, this study represents the gendered ideas in society that govern the women entrepreneurs' behaviour and self-perception. This study also contributes to the expansion of border theory by advocating the integration between different spheres of life. Our study finds that instead of ease in transition and high level of integration between work and family domains, home-based businesses facilitate women entrepreneurs to achieve work-life balance. However, this is not realized without sacrifices and assistance. We also found that resources in the family help to maintain work-life balance for the entrepreneurs, and family-oriented growth strategies include utilizing the family resources to compensate for their unavailability at home, such as relying on the elder family members or hiring help for domestic work and childcare. The study also reports business-oriented growth strategies adopted by women entrepreneurs for efficiently managing 
their family and domestic responsibilities. Particularly, they use the benefit of being the boss, scheduling flexible working hours and redesigning work settings to better take care of family responsibilities.

\subsection{Practical implications}

Most of the women entrepreneurs who participated in this study seem to be a continuous struggle to manage their business and family responsibilities. Hence, advanced consideration from the government is required to improve women entrepreneurship in Pakistan as majority of them claimed that they get insufficient support from government for their business set-up and expansion. Government has established departments such as SMEDA and Chamber of Commerce to promote small and medium businesses but their policies and schemes are not properly communicated to the targeted audience. Most of the women entrepreneurs are not registered with Chamber of Commerce due to inadequate information regarding functionality. Hence it is recommended that existing policies be effectively communicated to women entrepreneurs through a variety of channels (e.g. print and electronic media). Supporting women entrepreneurs in their small and home-based businesses will contribute to the national economy.

\subsection{Limitations and future research}

Even though this study makes several contributions to research, its limitations must be acknowledged. Our sample was composed exclusively of entrepreneurs in pre-Covid-19 period, however, we argue at the onset that flexibility and permeability are growing features of other occupations in Covid-19 era as world is shifting to online work or work from home. One could argue that the findings presented here are of potential interest to the broader population of workers, given that the typical entrepreneurial traits of independence, challenge, and self- realization (Ezzedeen \& Zikic, 2017) have become more sought after in corporate environments. Therefore, we encourage researchers to examine whether the various model elements unveiled here apply to other occupations. For example, can corporate employees manage work-life boundaries in the same way? Are their work-life strategies traceable to factors similar to those identified here?

\section{References}

Adisa, T. A., Gbadamosi, G., Mordi, T., \& Mordi, C. (2019). In search of perfect boundaries? Entrepreneurs' work-life balance, Personnel Review, 48 (6), 1634-1651.

Agarwal, R. (2017). Contributions made by women entrepreneurs in augmenting socio regional-economic growth of emerging market economy. Journal of Women's Entrepreneurship and Education, 1(2), 87-100. 
Agarwal, S., \& Lenka, U. (2015). Study on work-life balance of women entrepreneurs - review and research agenda. Industrial and Commercial Training, 47(7), 356-362.

Al-Dajani, H., \& Marlow, S. (2010). Impact of women's home based enterprise on family dynamics: Evidence from Jordan. International Small Business Journal, 28(5), 470-486.

Aldrich, H. E., \& Cliff, J. E. (2003). The pervasive effect of family on entrepreneurship, Towards a family embeddedness perspective. Journal of Business Venturing, 18(3), 573-597.

Ali, F. (2013). A multi-level perspective on equal employment opportunity for women in Pakistan. Equality, Diversity and Inclusion: An International Journal, 32(3), 5-15.

Allen, T. D., French, K. A., Dumani, S., \& Shockley, K. M. (2020). A cross-national meta-analytic examination of predictors and outcomes associated with work-family conflict. Journal of Applied Psychology, 105(6), 539-547.

Alsos, G. A., Ljunggren, E., \& Carter, S. (2016). Women , family and entrepreneurship : strategies for managing work-life balance challenges. Academy of Management Proceedings, 19-33.

Amjad, S. (2013). Why Pakistan has not reaped its demographic dividend? In Z. A. Sathar, R. Royan, \& Bongarts (Eds.), Capturing the demographic dividend in Pakistan (pp. 25-40). NY: Population Council Incorporation.

Anwar, M. U., \& Rashid, A. G. (2012). Female Entrepreneurs - A Review of the Literature and Proposed Conceptual Framework. Proceedings of 2nd International Conference on Business Management, 1-30.

Arifeen, S. R. 2008. A biographical profile of professional women managers in Pakistan's private sector. Oxford Business and Economics Conference. UK: Oxford Publications.

Ashforth, B. E., Kreiner, G. E., \& Fugate, M. (2000). All in a day's work: Boundaries and micro role transitions. Academy of Management Review, 25, 472-491.

Barsh, J., Crawford, B., \& Grosso, C. (2000). How e-tailing can rise from the ashes. The McKinsey Quarterly, 3, 98-109.

Baughn, C.C., Chua, B.L. and Neupert, K.E. (2006). The normative context for women's participation in entrepreneurship: a multi-country study. Entrepreneurship Theory and Practice, 30(5), 687-708.

Bellavia, G., \& Frone, M. R. (2005). Work-family conflict. In J. Barling (Ed.), Handbook of work stress. California: Sage.

Bird, J. (2006). Workllife balance: doing it right and avoiding the pitfalls. Employment Relations Today, $33(3), 21-30$.

Brush, C. G., Bruin, A. de, \& Welter, F. (2009). A gender-aware framework for women's entrepreneurship. International Journal of Gender and Entrepreneurship, 1(1), 8-24.

Byron, K. (2005). A meta-analytic review of work-family conflict and its antecedents. Journal of Vocational 
Behavior, 67(2), 169-198.

Casper, W. J., Vaziri, H., Wayne, J. H., \& DeHauw, S. (2018). The jingle-jangle of work-nonwork balance: A comprehensive and meta-analytic review of its meaning and measurement. Journal of Applied Psychology, 103(2), 182-214.

Clark, S. (2000). Work/family border theory: A new theory of work/family balance. Human Relations, 53(6), 747-770.

Creswell, J. W. (2014). Research Design Qualitative, Quantitative and Mixed Methods Approaches (4th ed.). California: Sage Publications:

Davies, J., Yarrow, E., \& Syed, J. (2020). The curious underلrepresentation of women impact case leaders: Can we disengender inequality regimes?. Gender, Work $\mathcal{E}$ Organization, 27(2), 129-148.

De Lange, A., Kooij, D., \& Heijden, B. (2015). Human resource management and sustainability at work across the lifespan: An integral perspective. In L. Finkelstein, D. Truxillo, F. Fraccaroli, \& R. Kanfer (Eds.), Facing the challenges of a multi-age workforce: A use-inspired approach (pp. 50-80). New York: Routledge.

Duberley, J., \& Carrigan, M. (2012). The career identities of 'mumpreneurs': Women's experiences of combining enterprise and motherhood. International Small Business Journal, 31(6), 629-651.

Eddleston, K. A., \& Powell, G. N. (2012). Nurturing entrepreneurs' work-family balance: a gendered perspective. Entrepreneurship: Theory and Practice, 36(3), 513-541.

Edralin, D. M. (2012). Innovative work-life balance strategies of filipina entrepreneurs: New evidence from survey and case research approaches. Procedia - Social and Behavioral Sciences, 57, 201-208.

Ekinsmyth, C. (2011). Geoforum challenging the boundaries of entrepreneurship : The spatialities and practices of UK 'Mumpreneurs.' Geoforum, 42(1), 104-114.

Ekinsmyth, C. (2014). Mothers ' business, work / life and the politics of ' mumpreneurship'. A Journal of Feminist Geography, 21(10), 1230-1248.

Ezzedeen, S. R., \& Zikic, J. (2017). Finding balance amid boundarylessness: An interpretive study of entrepreneurial work-life balance and boundary management. Journal of Family Issues, 38(11), 1546-1576.

Faiz, R. (2015). Work-family conflict: A case study of women in Pakistani banks. Unpublished doctoral dissertation, University of Hertfordshire, United Kingdom. Retrieved from: https://uhra.herts.ac.uk/ bitstream/handle/2299/16037/10289054\%20Faiz\%20Rafia\%20.

Friedman, S. D., \& Greenhaus, J. H. (2000). Work and family-allies or enemies?: what happens when business professionals confront life choices. Oxford University Press: New York.

Goffee, R., \& Scase, R. (2015). Women in charge (routledge revivals): The experiences of female entrepreneurs. New York: Routledge. 
Gronlund, A. (2007). More control, less conflict? Job demand-control, gender and work-family conflict. Gender, Work E Organization, 14(5), 476-97.

Gupta, V. K., Turban, D. B., Arzu, S. W., \& Sikdar, A. (2009). The role of gender stereotypes in perceptions of entrepreneurs and intentions to become an entrepreneur. Entrepreneurship Theory and Practice, 33(2), 397-417.

Greenhaus, J. H., \& Allen, T. D. (2011). Work family balance: A review and extension of the literature. In J. C. Quick \& L. E. Tetrick (Eds.), Hand book of occupational health psychology (2nd ed., pp. 165-183.). Washington DC: American Psychological Association.

Greenhaus, J. H., \& Parasuraman, S. (1999). Research on work, family, and gender: Current status and future directions. In G. N. Powell (Ed.), Handbook of gender and work (pp. 391-412). Sage Publications.

Hakeem, S., \& Aijaz, U. (2017). Woman's irreplaceable contribution to Pakistan's economic growth-Women empowerment and economic development. Retrieved from https://www.pakistangulfeconomist. com/2017/09/25/womans-irreplaceable-contribution-pakistans-economic-growth-women-empowerment-economic-development/

Helmy, F. F., Aljiuad, R. M., Alsufyani, M. H., Alsufyani, S. A., \& Alkhadi, A. S. (2017). Mother's Awareness about Different Types of Child Abuse in Taif Region (Western KSA). EC Paediatrics, 5(4), 89-96.

Henry, C., Foss, L., \& Ahl, H. (2016). Gender and entrepreneurship research: A review of methodological approaches. International Small Business Journal: Researching Enterpreneurship, 34(3), 217-241.

International Labour Organization. (2017). Facts on women at work. Retrieved from http://www.ilo.org/ gender/lang-en/index.htm.

Jennings, J. E., \& Mcdougald, M. S. (2007). Work-family interface experiences and coping strategies: Implications for enterpreneurship research and practice. Academy of Management Review, 32(3), 747-760.

Jennings, J. E., Breitkreuz, R. S., \& James, A. E. (2013). When family members are also business owners: Is entrepreneurship good for families? Family Relations, 62(3), 472-489.

Jennings, J. E., \& Brush, C. G. (2013). Research on Women Entrepreneurs: Challenges to (and from) the Broader Entrepreneurship Literature? The Academy of Management Annals, 7(1), 663-715.

Joona, P. (2018). How does motherhood affect self-employment performance? Small Business Economics, 50(1), 29-54.

Khan, G., Naveed, R. T., \& Hamzah-Bin-Jantan, A. (2018). Status of wonder women: Challenges for young future women entrepreneurs in Pakistan. International Journal of Experiential Learning $\mathcal{B}$ Case Studies, 3(1). 12-28.

Khandelwal, P., \& Sehgal, A. (2018). Exploring work-family interface for Indian women entrepreneurs. Gender in Management: An International Journal, 33(3), 203-216. 
Ko, E., \& Megehee, C. M. (2012). Fashion marketing of luxury brands: Recent research issues and contributions. Journal of Business Research, 65, 1395-1398.

Labour Force Survey. (2017). Labour Force Survey. Islamabad: Federal Bureau of Statistics, Statistics Division.

Laudano, M. C., Zollo, L., Ciappei, C., \& Zampi, V. (2019). Entrepreneurial universities and women entrepreneurship: a cross-cultural study. Management Decision, 57(9), 2541-2554.

Marlow, S., \& McAdam, M. (2013). Gender and entrepreneurship: Advancing debate and challenging myths: Exploring the mystery of the under-performing female entrepreneurs. International Journal of Entrepreneurial Behavior and Research, 19(1), 114-124.

Martinengo, G., Jacob, J. I., \& Hill, E. J. (2010). Gender and the Work-Family Interface: Exploring Differences Across the Family Life Course. Journal of Family Issues, 31(10), 1363-1390.

Mathew, R. V., \& Panchanatham, N. (2011). An exploratory study on the work-life balance of women entrepreneurs in South India. Asian Academy of Management Journal, 16(2), 77-105.

Mazumdar, S. (2001). Rethinking public and private space: Religion and women in Muslim society. Journal of Architectural and Planning Research, 18(4), 302-324.

McBride, A., Hebson, G., \& Holgate, J. (2015). Intersectionality: are we taking enough notice in the field of work and employment relations?. Work, employment and society, 29(2), 331-341.

McGowan, P., Redeker, C. L., Cooper, S. Y., \& Greenan, K. (2012). Female entrepreneurship and management of business and domestic roles: Motivations, expectation and realities. Entrepreneurship and Regional Development, 24(1), 53-72.

Mokomane, Z. (2014). Work-family balance: Issues and considerations for the Post-2014 agenda. In J. Griffiths (Ed.)., Family Futures (pp. 180-182). London: Tudor Rose.

Molina, J.A. (2020). Family and entrepreneurship: New empirical and theoretical results. Journal of Family and Econimic Issues, 41, 1-3.

Ojo, J. (2006). Using SMEs to achieve millennium development goals: Challenges and prospects. Journal of Business Social Science, 7(2), 50-62.

Oliver, D. G., Serovich, J. M., \& Mason, T. L. (2005). Constraints and opportunities with interview transcription: Towards reflection in qualitative research. Social Forces, 84(2), 1273-1289.

Ozbilgin, M., \& Syed, J. (2010). Managing Cultural Diversity in Asia: A Research Companion. Cheltenham $\&$ New York: Edward Elgar.

Ozbilgin, M., Syed, J., \& Dereli, B. (2010). Managing gender diversity in Pakistan and Turkey: a historical review. In A. Klarsfeld (Ed.), International Handbook of Diversity Management of Work. New York: Edward Elgar. 
Ozbilgin, M. F., Beauregard, T. A., Tatli, A., \& Bell, M. P. (2011). Work-life, diversity and intersectionality: A critical review and research agenda. International Journal of Management Reviews, 13(2), 177-198.

Patton, M. Q. (2002). Qualitative Research And Evaluation Methods. Thousand Oaks, Sage Publication.

Poggesi, S., Mari, M., \& De Vita, L. (2019). Women entrepreneurs and work-family conflict: an analysis of the antecedents. International Entrepreneurship and Management Journal, 15(2), 431-454.

Rehman, S., \& Roomi, M. A. (2012). Gender and work-life balance:A phenomenological study of women entrepreneurs in Pakistan. Journal of Small Business and Enterprise Development, 19(2), 209-228.

Roomi, M. A., Rehman, S., \& Henry, C. (2018). Exploring the normative context for women's entrepreneurship in Pakistan: A critical analysis. International Journal of Gender and Entrepreneurship, 10, 158-180.

Rehman, S. (2015). A life course approach to understand work-life choices of women entrepreneurs: evidence from Pakistan. Middlesex University, London. Retrieved from https://eprints.mdx. ac.uk/18308/1/SRehmanThesis.pdf

Xia, R. (2015). Thesis Building a Bridge between Work-family Issues and Growth Intentions of Female Entrepreneurs. University of Ottawa, Canada. Retrieved from https://ruor.uottawa.ca/bitstream/10393/33403/1/ Xia_Ruoxi_2015_thesis.pdf

Rothausen, T. J. (2009). Management Work-Family Research and Work-Family Fit: Implications for Building Family Capital in Family Business. Family Business Review, 22(3), 220-234.

Ruderman, M. N. J., Ohlott, P., Panzer, K., \& King, S. N. (2002). Benefits of multiple roles for managerial women. Academy of Management Journal, 45(2), 369-386.

Shah, S. S. (2014). The Role of Work-Family Enrichment in Work-Life Balance $\mathcal{E}$ Career Success. Ludwig-Maximilians-University, Munich, Germany. Retrieved from https://edoc.ub.uni-muenchen.de/16634/

Shelton, L. M. (2006). Female entrepreneurs, work-family conflict, and venture performance: new insights into the work-family interface. Journal of Small Business Management, 44(2), 285-297.

Simon, M., Houghton, S. M., \& Aquino, K. (2000). Cognitive biases, risk perception, and venture formation, how individuals decide to start companies. Journal of Business Venturing, 15(2), 113-134.

Sirgy, M. J., \& Lee, D. J. (2018). Work-life balance: An integrative review. Applied Research in Quality of Life, 13(1), 229-254.

Smith, J. A. (2004). Reflecting on the development of interpretive phenomenological analysis and its contribution to qualitative research in psychology. Qualitative Research in Psychology, 1, 39-54

Syed, J., \& Ali, F. (2019). Theorizing equal opportunity in Muslim majority countries. Gender, Work \& Organization, 26(11), 1621-1639. 
Thébaud, S. (2016). Passing Up the Job: The Role of Gendered Organizations and Families in the Entrepreneurial Career Process. Entrepreneurship Theory and Practice, 40(2), 269-287.

Ward, L. (2007). Taking care of business: The government suggests becoming an entrepreneur is the perfect way for women to achieve work-life balance. But is it all it is cracked up to be. United Kingdom: The Guardian. Reterived from https://www.theguardian.com/money/2007/mar/23/genderissues.worklifebalance World Bank. (2017). Pakistan Development update. Karachi: World Bank.

Yang, S., Song, Y., \& Tong, S. (2017). Sustainable retailing in the fashion industry:a systematic literature review. Sustainability,17(2), 2-19.

Yeung, G., \& Ang, K. L. (2016). Online fashion retailing and retail geography: The blogshop phenomenon in Singapore. Tijdschrift Voor Economische En Sociale Geografie, 107(2), 81-99. 


\begin{tabular}{|c|c|c|c|c|c|c|c|c|c|c|c|c|}
\hline 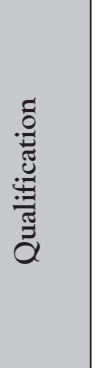 & 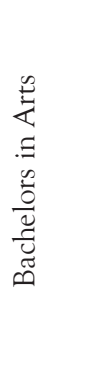 & 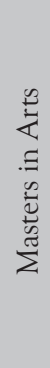 & 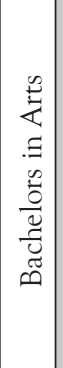 & 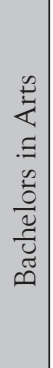 & 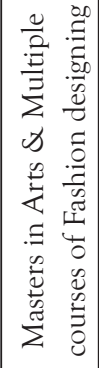 & 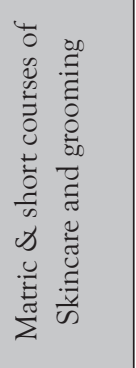 & 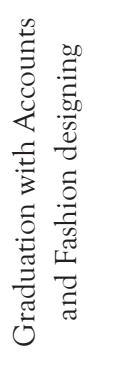 & 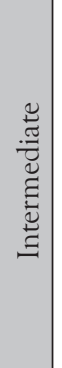 & 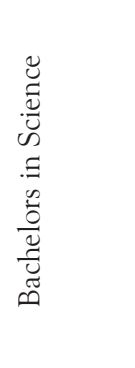 & 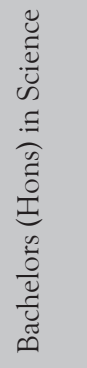 & 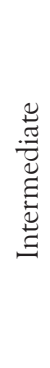 & $\frac{\frac{0}{0}}{\frac{0}{\Sigma}}$ \\
\hline 离 & ' & $\sim$ & . & $\sim$ & $\sim$ & $\sigma$ & $\sim$ & - & $n$ & 0 & $m$ & $\leftarrow$ \\
\hline 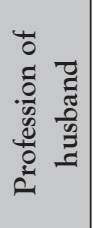 & 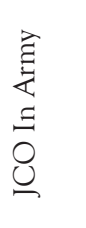 & $\begin{array}{l}\frac{\partial}{0} \\
\frac{\pi}{\omega} \\
\frac{0}{0} \\
\frac{0}{2}\end{array}$ & ' & 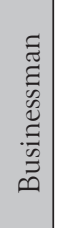 & 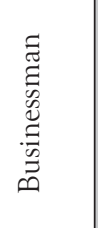 & 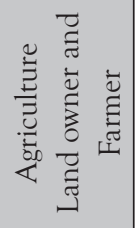 & 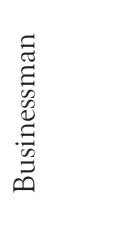 & 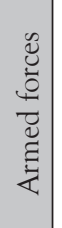 & 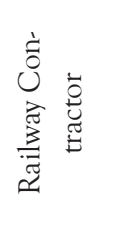 & 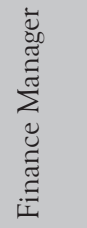 & 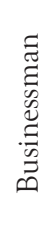 & ' \\
\hline 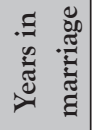 & - & $a$ & ' & $\tilde{\sim}$ & $\stackrel{\infty}{\sim}$ & $\tilde{\sim}$ & $\stackrel{\sim}{\sim}$ & $a$ & $\vec{\sim}$ & $\checkmark$ & + & 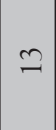 \\
\hline 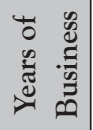 & - & $\sim$ & 0 & in & $\simeq$ & $\simeq$ & $\stackrel{\infty}{\sim}$ & 0 & $\simeq$ & $\sim$ & $a$ & $\nabla$ \\
\hline 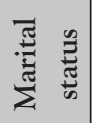 & 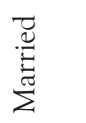 & 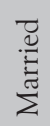 & $\begin{array}{l}\stackrel{0}{80} \\
\stackrel{\varpi}{\leftrightarrows}\end{array}$ & 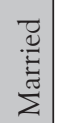 & 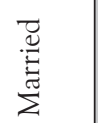 & 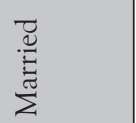 & 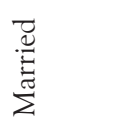 & 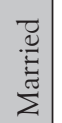 & 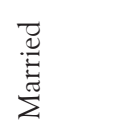 & 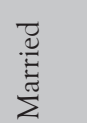 & 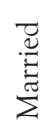 & $\frac{3}{0}$ \\
\hline 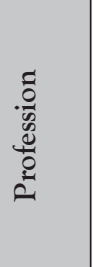 & 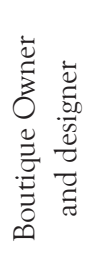 & 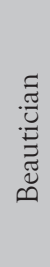 & 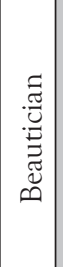 & 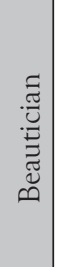 & 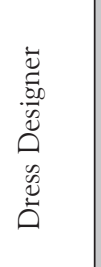 & 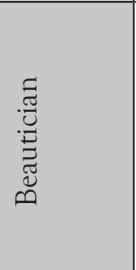 & 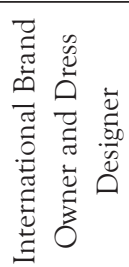 & 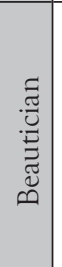 & 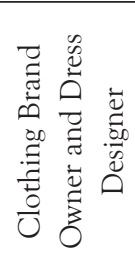 & 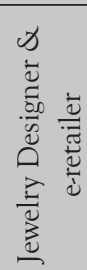 & 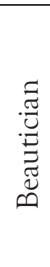 & 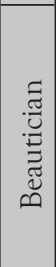 \\
\hline$\frac{80}{4}$ & $\tilde{\sim}$ & $\approx$ & $\stackrel{\sim}{\sim}$ & $\stackrel{\infty}{+}$ & テ & テ & $\stackrel{n}{f}$ & $\hat{m}$ & 웅 & $\approx$ & $\stackrel{\infty}{\sim}$ & $\approx$ \\
\hline $\begin{array}{l}\text { İ } \\
\text { Z }\end{array}$ & $\bar{a}$ & $\tilde{\approx}$ & $\tilde{\Omega}$ & $\stackrel{+}{ \pm}$ & $\curvearrowleft$ & 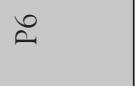 & $\tilde{a}$ & $\stackrel{\infty}{\propto}$ & 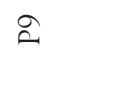 & $\stackrel{0}{a}$ & 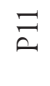 & $\stackrel{\sim}{a}$ \\
\hline
\end{tabular}




\begin{tabular}{|c|c|c|c|c|c|c|c|c|c|c|c|}
\hline 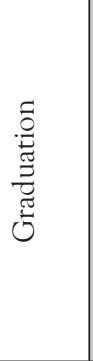 & 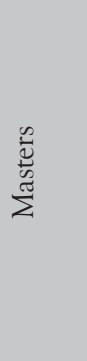 & 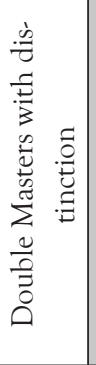 & $\begin{array}{l}\stackrel{.}{\vec{E}} \\
\stackrel{\pi}{\Sigma}\end{array}$ & 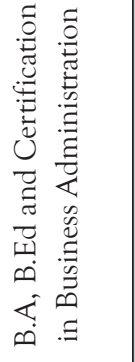 & $\begin{array}{l}D_{0}^{\infty} \\
0 \\
\text { I } \\
\infty \\
\infty\end{array}$ & 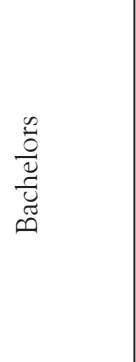 & 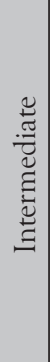 & 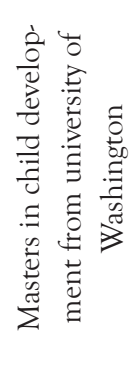 & 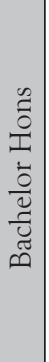 & 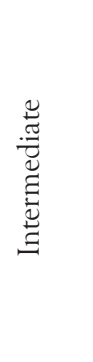 & 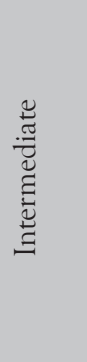 \\
\hline$n$ & $m$ & $\sim$ & $\nabla$ & $\sim$ & . & - & , & $n$ & . & $m$ & $\sim$ \\
\hline 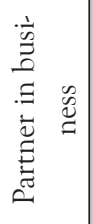 & 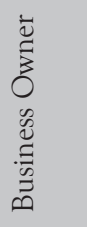 & 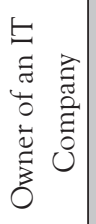 & 1 & 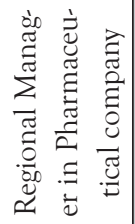 & . & 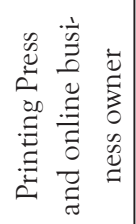 & . & 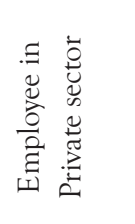 & . & 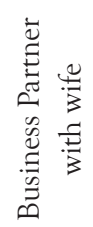 & ' \\
\hline$\stackrel{2}{\sim}$ & $\simeq$ & $\infty$ & ㅇ & 으 & . & 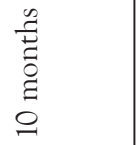 & . & $\approx$ & . & $\stackrel{n}{\simeq}$ & 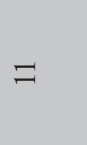 \\
\hline- & $\forall$ & - & in & t & - & + & $\sim$ & 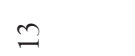 & $\sim$ & in & in \\
\hline 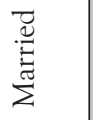 & $\begin{array}{l}\stackrel{D}{\mathscr{E}} \\
\stackrel{\vec{E}}{\Sigma}\end{array}$ & 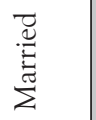 & $\begin{array}{l}3 \\
\frac{3}{0} \\
\frac{0}{2} \\
3\end{array}$ & 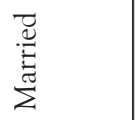 & $\begin{array}{l}\frac{\stackrel{0}{\Delta 0}}{\leftrightarrows} \\
\dot{\omega}\end{array}$ & 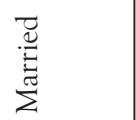 & $\begin{array}{l}\stackrel{0}{00} \\
\stackrel{\sim}{\infty}\end{array}$ & 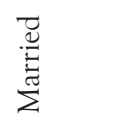 & $\begin{array}{l}\stackrel{0}{\infty 0} \\
\stackrel{\varpi}{\sigma}\end{array}$ & 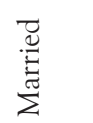 & $\frac{3}{\frac{3}{0}}$ \\
\hline 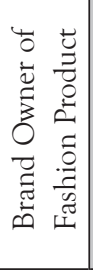 & 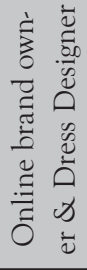 & 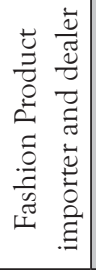 & 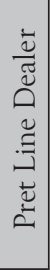 & 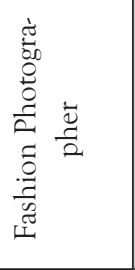 & 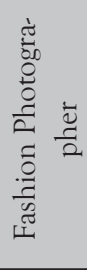 & 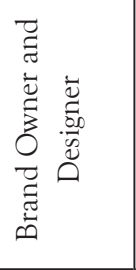 & 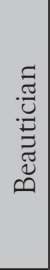 & 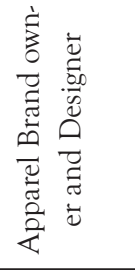 & 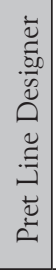 & 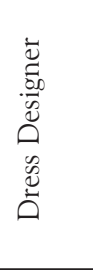 & 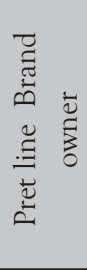 \\
\hline$\prod_{n}^{\infty}$ & 우 & $\approx$ & F & શે & $\stackrel{\infty}{\sim}$ & 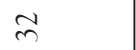 & $\approx$ & $\stackrel{F}{\forall}$ & $\vec{\sim}$ & $n$ & N \\
\hline$\stackrel{n}{a}$ & $\frac{\Delta}{a}$ & $\stackrel{n}{2}$ & $\stackrel{b}{a}$ & $\bar{\Xi}$ & $\stackrel{\infty}{a}$ & $\stackrel{\partial}{\vec{a}}$ & $\underset{\Xi}{\Xi}$ & $\overrightarrow{\widetilde{Z}}$ & $\widetilde{\Xi}$ & 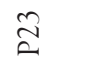 & 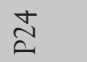 \\
\hline
\end{tabular}




\begin{tabular}{|c|c|c|c|c|c|c|c|c|c|c|}
\hline 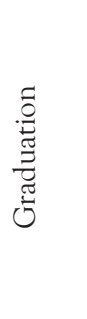 & 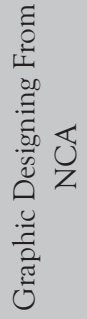 & 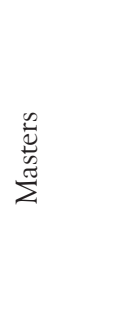 & 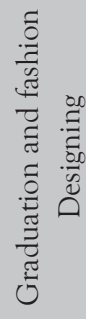 & 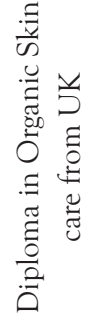 & 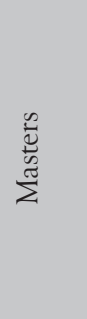 & 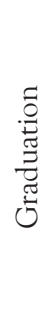 & 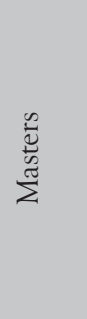 & $\underbrace{\stackrel{U}{E}}_{\stackrel{U}{E}}$ & 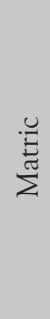 & $\begin{array}{l}\bar{\Xi} \\
\dot{\Sigma} \\
\dot{\Sigma}\end{array}$ \\
\hline$\sim$ & $m$ & . & $\sim$ & $\underset{\sim}{\stackrel{\Delta}{0}} \underset{0}{0}$ & 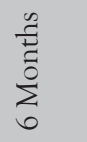 & $m$ & . & in & 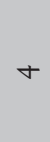 & ' \\
\hline 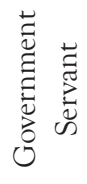 & 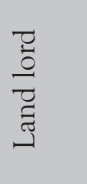 & ' & 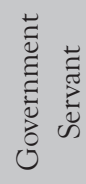 & . & 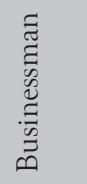 & 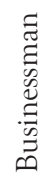 & 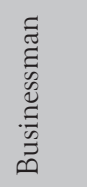 & 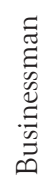 & 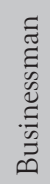 & 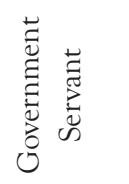 \\
\hline$\cong$ & ㄷ & ' & $\simeq$ & $\neg$ & $\sim$ & $\approx$ & 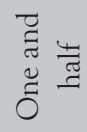 & $\beth$ & $\stackrel{12}{\sim}$ & 0 \\
\hline$\stackrel{\sim}{\beth}$ & 귀 & $\sim$ & $\sim$ & in & in & ㄱ) & - & $\sim$ & 으 & ナ \\
\hline $\begin{array}{l}\stackrel{\overrightarrow{\mathscr{V}}}{\vec{E}} \\
\stackrel{\vec{J}}{\Sigma}\end{array}$ & 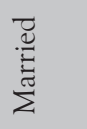 & $\begin{array}{l}\frac{\ddot{0}}{30} \\
\stackrel{\Xi}{\infty}\end{array}$ & 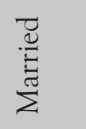 & 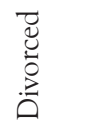 & 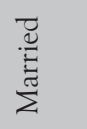 & 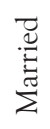 & $\begin{array}{l}\stackrel{\bar{U}}{\underline{E}} \\
\stackrel{\bar{J}}{\Sigma}\end{array}$ & 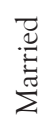 & $\frac{\vec{d}}{\stackrel{\Xi}{E}}$ & 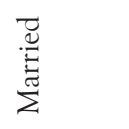 \\
\hline 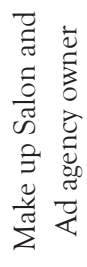 & 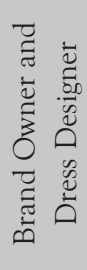 & 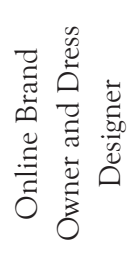 & 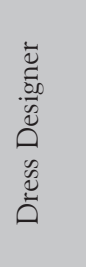 & 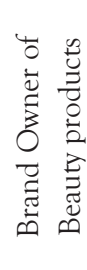 & 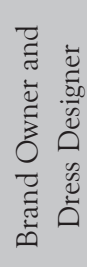 & 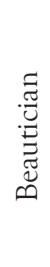 & 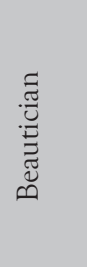 & 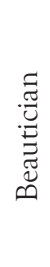 & 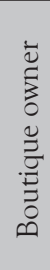 & 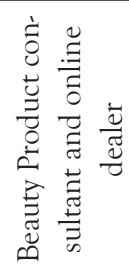 \\
\hline$\stackrel{\Re}{\circledR}$ & $\mathcal{F}$ & $\vec{\sim}$ & $\stackrel{\infty}{m}$ & $\tilde{n}$ & $\stackrel{\sim}{\sim}$ & $\stackrel{\sim}{\sim}$ & $\stackrel{\sim}{\sim}$ & $n$ & in & $\approx$ \\
\hline$\stackrel{\Perp}{\tilde{C}}$ & $\underset{\sim}{\tilde{\Xi}}$ & $\widetilde{\Xi}$ & 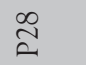 & 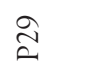 & $\stackrel{\overbrace{}}{\approx}$ & $\overline{\tilde{n}}$ & $\tilde{\tilde{\varkappa}}$ & $\tilde{\tilde{\epsilon}}$ & $\stackrel{ \pm}{\tilde{\omega}}$ & $\tilde{n}$ \\
\hline
\end{tabular}


